UDC $57.088+57.053$

\title{
Personalized responsiveness of human PBMCs to the action of IL-7
}

\author{
M. V. Kovalchuk ${ }^{1}$, T. A. Ruban ${ }^{1}$, M. O. Usenko ${ }^{1}$, V. A. Kordium ${ }^{1}$ \\ ${ }^{1}$ Institute of Molecular Biology and Genetics, NAS of Ukraine \\ 150, Akademika Zabolotnoho Str., Kyiv, Ukraine, 03143 \\ kovmv@ukr.net
}

\begin{abstract}
Interleukin-7 (IL-7) is an important element in the functioning of the immune system. Therefore, it would be appropriate to assess individual responses of the immune cells to IL-7. Aim. To analyze ex vivo responses of the healthy adult individual T cells to increasing rhIL-7 concentrations. Methods. Isolation and cultivation of PBMCs and in vitro cytokine bioassay. Quantitative determination of cell viability was performed by the metabolic MTT-uptake assay in viable cells. $\mathrm{EC}_{50}$ was calculated by means of OriginPro7,5. Results. The dose-response effect on T cell subsets of PBMCs for different concentrations of rhIL-7 in individuals in vit$r o$ was evaluated. IL-7 bioassay revealed that the individual $\mathrm{EC}_{50}$ values ranged from 0.41 to $1.5 \mathrm{ng} / \mathrm{ml}$. Inter-individual variability was high for $\mathrm{EC}_{50}$ values $\left(\mathrm{CV}_{\mathrm{G}}=38 \%\right)$. Maximal percentage increase in cell viability among subjects demonstrated moderate variability $\left(\mathrm{CV}_{\mathrm{G}}=15 \%\right)$. Conclusions. The study revealed that responsiveness to IL-7 is various for the PBMCs originated from different individuals. Our research assumes that the personalized responsiveness of human PBMCs to IL-7 may be considered as valuable prognostic information about the immune system state and the T cells response to IL-7-based therapies. The advantage of the optimized bioassay for the detection sensitivity of PBMC response to IL-7 was shown.
\end{abstract}

K e y w o r d s: IL-7, PBMCs, inter-individual variability.

\section{Introduction}

Interleukin-7 (IL-7) is an essential element in the immune system functioning, specifically, in lymphopoiesis and $\mathrm{T}$ cell development. The cytokine was initially identified by Namen et al. for its ability to stimulate B lymphopoiesis [1]. Now it has been shown that IL-7 plays a critical role in modulating T-cell function in vivo $[2,3]$. Furthermore, numerous recent re- searches have demonstrated that IL-7 might serve as an effective adjuvant, which can modulate immune responses and strongly elicit protective immunity $[4,5]$.

Regulation of the IL-7 action depends on IL-7 receptors (IL-7R) on cells. The IL-7R functioning has some peculiarities. First, whereas the common gamma chain $\left(\gamma_{c}\right)$ cyto-

(C) 2020 M. V. Kovalchuk et al.; Published by the Institute of Molecular Biology and Genetics, NAS of Ukraine on behalf of Biopolymers and Cell. This is an Open Access article distributed under the terms of the Creative Commons Attribution License (http://creativecommons.org/licenses/by/4.0/), which permits unrestricted reuse, distribution, and reproduction in any medium, provided the original work is properly cited 
kine receptors are up-regulated following $\mathrm{T}$ cell activation, the expression of IL-7R alpha chain is lost on the effector cells, but then reexpressed on the memory cells $[6,7]$. Second, it has been shown that differences in biological responses may be associated not only with the relative distribution of immune cells, but also with the absolute amount of IL-7R molecules on single cells, which can vary from 18452 to 61228 (mean value) in PBMCs from healthy donors [8]. Third, the amount of IL-7 receptors expressed on a cell is fine-tuned by receptor internalization and suppressor of cytokine signaling proteins. The half-life of IL-7R $\alpha$ decreases from 24 hours to approximately 3 hours after IL-7 treatment [9, 10]. And finally, IL-7 binds strongly to heparin sulfate proteoglycans in the extracellular matrix in vivo and does not form a linear gradient from producing cells [11]. Together, these data suggest that IL-7/IL-7R signalling axis participates in many functions of immune system, and perturbation of this pathway is associated with immune disorders.

IL-7 is currently undergoing a number of clinical trials and the use of rhIL-7 has been attempted. The persona characterization of immune cells with respect to cytokine responsiveness and the variation of immune responses among individuals can provide valuable prognostic information for practical use. To date, inter-individual differences in the PBMC responsiveness to IL-7 have not been studied systemically. Thus, the aim of this pilot study was to assess in vitro the personalized responsiveness of PBMCs to increasing doses of rhIL-7 and inter-individual variability of the cell responses in healthy individuals.

\section{Materials and Methods}

Peripheral blood cell isolation. Cell preparation and culture. Venous peripheral blood samples were obtained from 18 healthy agematched individuals (age range $24-50$ years, males) and processed within $2 \mathrm{~h}$. Primary PBMCs were isolated by Ficoll-Hypaque (Ficoll-Hypaque Plus, GE Healthcare, Sweden) density gradient centrifugation following the manufacturer's instructions and resuspended in complete medium (RPMI 1640 supplemented with $10 \%$ FCS, $50 \mu \mathrm{M} 2-\beta$-Mercoptoethanol, and penicillin/streptomycin). The viability of mononuclear cells was assessed by the trypan blue dye exclusion test, and it was always more than $95 \%$.

\section{IL-7 bioassay and assay optimization}

The PBMC responsiveness to the action of rhIL-7 was measured in MTT cell viability assay using PHA-activated human peripheral blood lymphocytes. Activated T lymphocytes were obtained by cultivation of PBMCs at a density of $1 \times 10^{6} / \mathrm{ml}$ for 3,5 and 6 days with $10 \mu \mathrm{g} / \mathrm{ml}$ PHA (Sigma HA-15) in $25-\mathrm{cm}^{2}$ flasks at $37^{\circ} \mathrm{C} 5 \% \mathrm{CO}_{2}$ in a humidified incubator. Mitogen responses were terminated on days 3, 5 , and 6 . The PHA-activated cells in vitro were harvested and washed three times in cytokine free RPMI $+2 \%$ FCS. $50 \mu 1$ of the cell suspension were] seeded in triplicates into the wells of the flat-bottomed 96-wells plate $\left(1 \times 10^{5}\right.$ per well $)$. To assess cytokine-mediated effects, the cells were subsequently treated with varying concentrations of rhIL-7 (PeproTech, USA) for 72, 120, and $144 \mathrm{~h}$. The stock treatment IL-7 solution was made up to $1 \mathrm{mg} / \mathrm{ml}$ in PBS with $0.1 \%$ BSA. The solution was then adjusted to the indicated concentra- 
tion, using culture medium. $50 \mu \mathrm{l}$ of each treatment solution were then dispensed into each well in triplicate. The final volume in each well was $100 \mu \mathrm{l}$ and the IL-7 concentration was $62.5,125,250,500,1000,2000,3000,4000$, 5000 and $6000 \mathrm{pg} / \mathrm{ml}$. The plates were taken out after incubation and MTT cell viability assay was carried out [12]. All rhIL-7 samples used in this study were from the same bulk production lot.

Graphs and Statistical Analysis. The doseresponse curves were created for each PBMC sample, using the photometric results for different indicated cytokine concentrations. Data were presented as means \pm standard deviation (SD). The results of cytokine-induced activation were expressed as cell viability. Quantitative determination of cell viability of PBMCs was performed using metabolic MTTuptake assay and evaluated comparing cell optical density at different IL-7 concentrations with the same values after starting the cultivation without IL-7 taken as $100 \%\left(\mathrm{OD}_{\mathrm{x}} /\right.$ $\left.\mathrm{OD}_{\text {contr }} \times 100 \%\right)$. Maximal percentage increase in cell viability was expressed as $\left(\mathrm{OD}_{\max } /\right.$ $\left.\mathrm{OD}_{\text {contr }}\right) \times 100 \%$. Inter-individual variability was expressed as a coefficient of variation $\mathrm{CV}_{\mathrm{G}}$ $(\%)=(1 \mathrm{SD} /$ mean $) \times 100 \%$ using the overall mean for each variable. The rhIL-7 $\mathrm{EC}_{50}$ was defined as the effective concentration of cytokine that elicits a $50 \%$ increase in cell viability in the bioassays. $\mathrm{EC}_{50}$-data were calculated by means of OriginPro 7,5 software using sigmoidal dose-response curves.

\section{Results}

A number of assays are focused on exploring effects of the agonists supplement on cellular receptors. The cell functional assays are fre- quently used to measure cell survival that is a result of downstream effects of the] IL-7R activation. The present study was undertaken to determine whether the individual PBMC responsiveness to rhIL-7, measured as survival of mitogen-stimulated PBMCs in vitro, might characterise individual functional status of IL-7 receptors in bloodstream. As a result, some questions emerge. First, what biological variations exist in the PBMC responsiveness among healthy individuals? For that a smallscale age-marched random sample was screened for IL-7 response ability. 18 healthy individuals with normal range of circulating white blood cell counts $(4.0-10.0) \times 10^{6}$ cells/ $\mathrm{ml}$ were enrolled in this study.

Second, for noticeable inter-individual difference some modifications of standard IL-7 bioassay were made. Supplementary experiments were designed to establish optimal conditions for getting a standard S-shaped or sigmoid curve used to analyse cell responsiveness to IL-7 since the obtained data on dose-response measurements do not always meet the requirements for the sigmoidality of the curve. We established that the IL-7 dose range 62.5$6000 \mathrm{pg} / \mathrm{ml}$ was optimal for the single doseresponse curve construction. The IL-7 dose in the range of $0.5-10 \mathrm{ng} / \mathrm{ml}$ resulted in the high dose-response curve type but not in S-shaped curve.

Next, the optimal periods between cell collection and PHA response termination as well as between the IL-7 administration and MTTtesting were determined. According to literature, the optimal levels of $\mathrm{T}$ cell mitogen responsiveness to PHA in adult PBMCs were after 5 days (optimal on the $6^{\text {th }}$ day) [13]. The time of PHA exposure was selected experi- 
mentally. PHA responses were terminated on days 3, 5 and 6 followed by preparation of cells for IL-7 treatment. Using PHA-activated PBMCs which were cultured with PHA for 5 days allowed getting better results for the logistic non-linear curve fit. The time of IL-7 exposure was selected experimentally also. An increase of cell viability was measured in the presence of IL-7 for the same individual PBMCs after $72 \mathrm{~h}$ and 144-h of IL-7 exposition. The responses of individual PBMCs are shown on representative graphs from 2 experiments (Fig. 1). The $\mathrm{EC}_{50}$ values in 144-h culture compared with those in 72-h culture revealed a dose-response shift of $0.943 \pm 0.117$ to $0.643 \pm 0.055 \mathrm{ng} / \mathrm{mL}$ for the same PBMCs and the cells became more sensitive to rhIL-7.

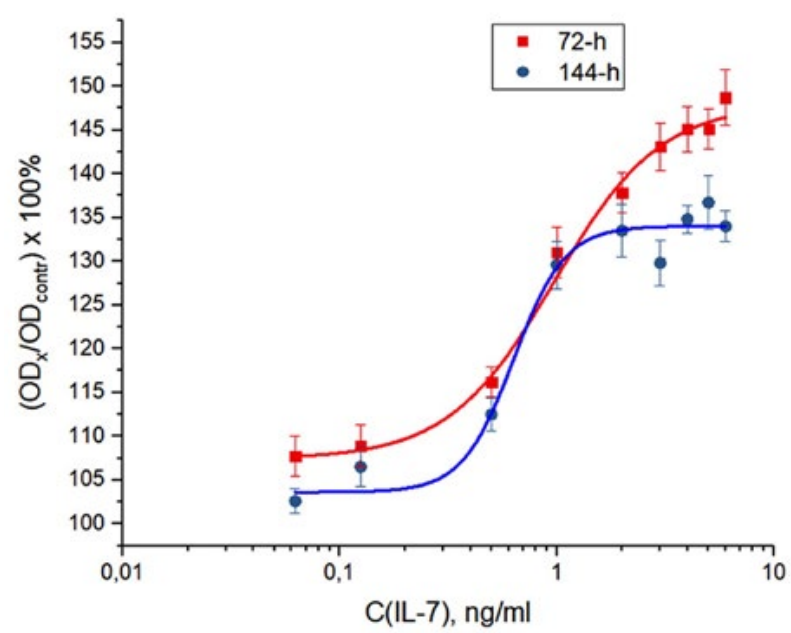

Fig. 1. Comparative dose-response effects of rhIL-7 on the identical individual cultured PBMCs in vitro following 72-h and 144-h IL-7 exposition period. Cells were stimulated with $0.0625,0.125,0.5,1,2,3,4,5$, and $6 \mathrm{ng} / \mathrm{ml}$ of IL-7. Survival data with fitted logistic regression lines are illustrated. Each point represents the mean $\left(\mathrm{OD}_{\mathrm{x}} / \mathrm{OD}_{\text {contr }}\right) \times 100 \% \pm \mathrm{SD}$. A log scale was used for $\mathrm{x}$-axis.
Since the duration of the analysis is important, and the shift in the value of $\mathrm{EC}_{50}$ is relatively small, we decided to stay at the 72-h IL-7 exposure. Thus, this assay allowed an assessment of the personalized PBMC responsiveness in the cellular response to IL-7 and evaluation of inter-individual variability.

Personalized cell viability was determined for each individual PBMC specimen and doseresponse curves were created. All graphs show the sigmoid curves for rising doses of rhIL-7. The IL-7 concentrations which lead to a $50 \%$ increase of cell survival $\left(\mathrm{EC}_{50}\right)$ were determined for each PBMC specimen and were in the range of $420-1540 \mathrm{pg} / \mathrm{ml}$. The $\mathrm{EC}_{50}$ values and maximal percentage increase in cell viability are shown in Table 1.

PBMC responsiveness to IL-7 was heterogeneous between individuals. $\mathrm{EC}_{50}$ values demonstrated high inter-individual variability. $\mathrm{CV}_{\mathrm{G}}$ was $38 \%$. The difference in sensitiveness to IL-7 among individuals was nearly 3 times, based on $\mathrm{EC}_{50}$ values. Although a significant variation of $\mathrm{PBMC}$ responsiveness to IL-7 was noted, several individual PBMCs were closely approximated to each other according to their functional IL-7 responsiveness that was demonstrated by the overlapping of dose-response curves. Additionally, comparable $\mathrm{EC}_{50}$ values were obtained, respectively for specimens $\mathrm{N} 1$ and $\mathrm{N} 3$ $(1.343 \pm 0.22 \mathrm{pg} / \mathrm{ml}$ and $1.337 \pm 0.125 \mathrm{pg} / \mathrm{ml})$, $\mathrm{N} 9$ and N17 $(767 \pm 0.089 \mathrm{pg} / \mathrm{ml}$ and $767 \pm 0.042$ $\mathrm{pg} / \mathrm{ml}), \mathrm{N} 7$ and N15 (1.028 $\pm 0.213 \mathrm{pg} / \mathrm{ml}$ and $1.029 \pm 0.21 \mathrm{pg} / \mathrm{ml}) . \mathrm{EC}_{50}$ variability was introduced in Fig. 2 and Table 1.

As for the response magnitude, the percentage increase in cell viability became maximal after $72 \mathrm{~h}$ incubation at the IL-7 concentra- 
M. V. Kovalchuk, T. A. Ruban, M. O. Usenko et al.

\begin{tabular}{c|c|c|}
\hline № specimen & $\mathrm{EC}_{50} \pm \mathrm{SD}(\mathrm{ng} / \mathrm{ml})$ & $\mathrm{OD}_{\max } / \mathrm{OD}_{\text {contr }} \times 100 \%$ \\
\hline 1 & $1.343 \pm 0.22$ & 125 \\
\hline 2 & $1.108 \pm 0.123$ & 127 \\
\hline 3 & $1.337 \pm 0.125$ & 139 \\
\hline 4 & $1.54 \pm 0.2$ & 179 \\
\hline 5 & $0.42 \pm 0.09$ & 122 \\
\hline 6 & $1.06 \pm 0.10$ & 194 \\
\hline 7 & $1.028 \pm 0.213$ & 125 \\
\hline 8 & $0.414 \pm 0.17$ & 128 \\
\hline 9 & $0.767 \pm 0.089$ & 118 \\
\hline \multicolumn{2}{|c}{}
\end{tabular}

\begin{tabular}{|c|c|c}
\hline № specimen & $\mathrm{EC}_{50} \pm \mathrm{SD}(\mathrm{ng} / \mathrm{ml})$ & $\mathrm{OD}_{\max } / \mathrm{OD}_{\text {contr }} \times 100 \%$ \\
\hline 10 & $0.735 \pm 0.096$ & 123 \\
\hline 11 & $0.642 \pm 0.071$ & 135 \\
\hline 12 & $0.943 \pm 0.117$ & 149 \\
\hline 13 & $0.506 \pm 0.106$ & 126 \\
\hline 14 & $0.507 \pm 0.123$ & 122 \\
\hline 15 & $1.029 \pm 0.21$ & 129 \\
\hline 16 & $1.457 \pm 0.163$ & 142 \\
\hline 17 & $0.767 \pm 0.042$ & 121 \\
\hline 18 & $1.067 \pm 0.073$ & 141 \\
\hline
\end{tabular}

tions $3 \mathrm{ng} / \mathrm{ml}$ and more. The IL-7-mediated cell survival of PBMCs was enhanced from $18 \%$ to $94 \%$ in comparison with the untreated cells. Maximal percentage increase in cell viability under IL-7 treatment was not significantly different among individual PBMCs. $\mathrm{CV}_{\mathrm{G}}$ for the variable was moderate at $15 \%$. Heterogeneity in the magnitude of $\mathrm{T}$ cell responsiveness to IL-7 among different individuals was presented in Fig. 2 and Table 1 as $\left(\mathrm{OD}_{\max } / \mathrm{OD}_{\text {contr }}\right) \times 100 \%$.

Discussion. IL-7 is currently under extensive investigation as a therapeutic agent in a
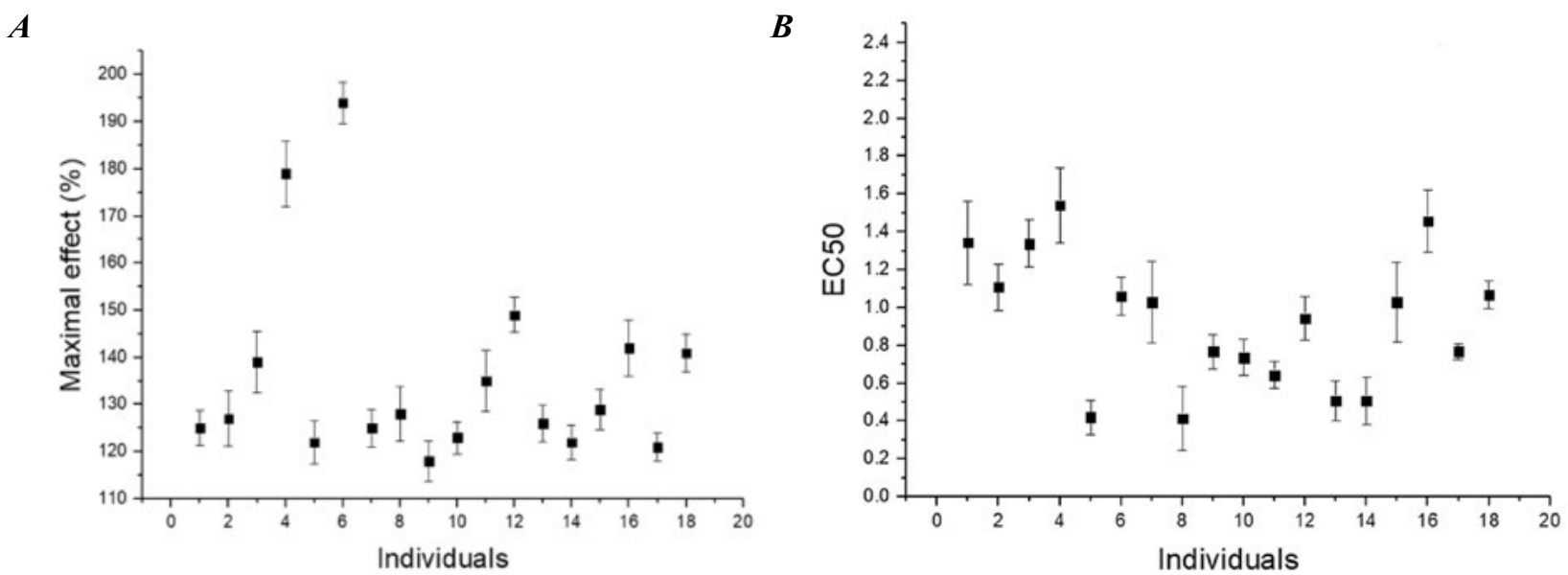

Fig. 2. Inter-individual variability of the PBMC responses to rhIL-7 in vitro $(\mathrm{n}=18)$. (a) Percentages of maximal effects to rhIL-7 in PBMCs $\left(\mathrm{CV}_{\mathrm{G}}=15 \%\right)$. (b) $\mathrm{EC}_{50}$ variability $\left(\mathrm{CV}_{\mathrm{G}}=38 \%\right)$. Each symbol represents the mean $\pm \mathrm{SD}$ of single individual PBMCs. 
some studies have demonstrated that there was no significant correlation between serum levels of IL-7 and clinical parameters in patients with several diseases.

As a result, the first question that arises is, "Can the responsiveness of PBMCs to IL-7 be an indicator of the state of the immune system, pharmacological responses to IL-7 treatment on cell physiological level or availability of IL-7 receptors?" It was reported that functional activity of IL-7 receptors can be assessed by the ability of exogenous IL-7 to stimulate the viability (survival + and/or IL-7induced apoptosis inhibition + proliferation) of freshly isolated immune cells. Such bioassays functionally assess the immediate cellular response to cytokine. To our knowledge, activation of $\mathrm{T}$ lymphocytes occurs in lymphoid tissue and generates functionally diverse subsets of effector $\mathrm{T}$ cells with the capacity to migrate to multiple tissue sites.

Unfortunately, in human, an assessment of immune cells in tissue sites (lymphoid or injured) is limited. Consequently, the next question that arises is "What types of circulation subsets of immune cells could respond to exogenous IL-7 in bioassay in vitro?" In general, an analysis of the blood $\mathrm{CD}^{+} \mathrm{T}$ and $\mathrm{CD} 8^{+} \mathrm{T}$ cells subsets as major responders to IL-7 revealed that they contained naïve, central memory (Tcm), effector memory (Tem), and terminally differentiated effector of $\mathrm{T}$ cell populations (Temra) [15].

It should nevertheless be noted that several peripheral blood $\mathrm{T}$ cell subsets remain unresponsive to IL-7 stimulation alone throughout the culture period [2, 16]. For these reasons, some ways exist to study cell responsiveness to IL-7 using T cells. Some in vitro systems could reproduce the in vivo models illustrating IL-7-related modulation of peripheral $\mathrm{T}$ cell homeostasis or even immune processes in local sites with high IL-7 levels. According to the literature two main types of study design prevail to assess $\mathrm{T}$ cell responsiveness to IL-7. On the one hand, because homeostatic survival and proliferation of T cells are dependent on signalling from TCR as well as on the IL7R activation by IL-7, the so called one-step costimulation assays with PHA plus IL-7 are often presented in literature. Human cells were co-stimulated with suboptimal concentrations of mitogen Leucoagglutinin PHA-L to enable proliferative responses to IL-7 [2, 17].

On the other hand, another stimulation scheme exists to assess IL-7 effect. It is a stepby-step approach. The first step is the PHAdriven culture. Only a small part of peripheral blood lymphocytes spontaneously divide in $v i$ tro but the majority enter the cell cycle following lectin stimulation. The PHA-activated expanded T cells are washed by cytokine-free medium and used for the second step of the assay for IL-7-driven culture. Then the cells are re-cultured in medium contained rhIL-7. We chose the second stimulation scheme, which allows us to use simultaneously the cells of the first step of the assay for other assays. Two parameters were found to be critical for detection of sensitivity in two-step assay and for inter-individual discrimination: prolongation of the time of the PHA-culture; and using low IL-7 doses (62.5-6000 pg/ml). There is an experimental evidence that after 5 days of PHA treatment some metabolic events lead to contraction of expanded $\mathrm{T}$ blasts. The expansion of activated $\mathrm{T}$ cells is accompanied by an increased sensitivity to apoptosis, which regu- 
lates proliferation and maintains lymphocyte homeostasis $[13,18,19]$. On the basis of our results we also hypothesize that some activated $T$ cells after 5 days of PHA-driven culture would be maintained by exogenous IL-7 due to apoptosis regulation. The same cells would be also more sensitive to low concentrations of IL-7. High doses of IL-7 in vitro have been demonstrated to stimulate $\mathrm{T}$ cell proliferation whereas low doses - to maintain homeostatic T cell survival. Noteworthy, rhIL-7 concentrations above $6 \mathrm{ng} / \mathrm{ml}$ did not improve the survival of the tested PBMCs. Moreover, in some cases, the cell survival at $5-6 \mathrm{ng} / \mathrm{ml}$ was lower than at $4 \mathrm{ng} / \mathrm{ml}$ and lower values of IL-7 concentration. This could be due to the fact that prolonged cultivation of $\mathrm{T}$ cells at high IL-7 concentrations results in the internalization of IL-7R on T cells.

There is significant heterogeneity in the immune responses in humans but the extent of variation is only starting to become clear [20, 21]. We tried to estimate inter-individual variability in PBMC responses to IL-7. The responses tended to vary markedly across individuals. There was substantial difference between healthy human subjects in the sensitivity to IL-7 according to values $\mathrm{EC}_{50}$. $\mathrm{CV}_{\mathrm{G}}$ for the variance was $38 \%$. Furthermore, high interindividual variability is characteristic for other parameters of the immune system. For example, based on the desirable biological variation database specifications www.westgard.com/ biodatabase1.htm, the variation coefficients $\left(\mathrm{CV}_{\mathrm{G}}\right)$ of $35.3 \%, 76.4 \%, 47.3 \%$ were reported for the lymphocyte count, eosinophils count and immunoglobulins $\mathrm{M}$, respectively. The magnitude of the response, expressed as the percentage increase in cell viability, had less inter-individual variation $\left(\mathrm{CV}_{\mathrm{G}}=15 \%\right)$ and was more appropriate for practical use.

Thus, the advantage of the optimized stimulation scheme on the detection sensitivity of PBMC responsiveness to rhIL-7 was shown. The present study revealed that the responsiveness to IL-7 is different for PBMCs originated from various individuals. The research suggests that the personalized responsiveness of human PBMNCs to IL-7 may be considered as valuable prognostic information about the immune system state and treatment response in $T$ cell subsets to IL-7-based therapies after confirmation by further validation in largescale study.

\section{REFERENCES}

1. Namen AE, Lupton S, Hjerrild K, Wignall J, Mochizuki DY, Schmierer A, Mosley B, March CJ, Urdal D, Gillis S. Stimulation of B-cell progenitors by cloned murine interleukin-7. Nature. 1988; 333:571-573.

2. Churchman SM, El-Jawhari JJ, Burska AN, Parmar R, Goëb V, Conaghan PG, Emery P, Ponchel F. Modulation of peripheral T-cell function by interleukin-7 in rheumatoid arthritis. Arthritis Res Ther. 2014; 16(6):511-524.

3. Kondrack RM, Harbertson J, Tan JT, McBreen ME, Surh CD, Bradley LM. Interleukin 7 Regulates the Survival and Generation of Memory CD4 Cells. J Exp Med. 2003; 198(12):1797-1806.

4. A Reum Kim, Junsik Park, Jong Hoon Kim, JeongEun Kwak, Youngran Cho, Hyojin Lee, Moonsup Jeong, Su-Hyung Park, Eui-Cheol Shin. Herpes Zoster DNA Vaccines with IL-7 and IL-33 Molecular Adjuvants Elicit Protective T Cell Immunity. Immune Netw. 2018. 18(5): e38.

5. Nam HJ, Song MY, Choi DH, Yang SH, Jin HT, Sung YC. Marked enhancement of antigen-specific T-cell responses by IL-7-fused nonlytic, but not lytic, Fc as a genetic adjuvant. Eur. J. Immunol. 2010; 40(2):351-358. 
6. Jianbao Gao, Lintao Zhao, Yisong Y Wan, Bo Zhu. Mechanism of Action of IL-7 and Its Potential Applications and Limitations in Cancer Immunotherapy. Int J Mol Sci. 2015; 16(5):10267-10280.

7. Mazzucchelli R, Durum SK. Interleukin-7 receptor expression: intelligent design. Nat Rev Immunol. 2007; 7:144-154.

8. Vudattu NK, Kuhlmann-Berenzon S, Khademi M, Seyfert V, Olsson T, Maeurer MJ. Increased Numbers of IL-7 Receptor Molecules on CD4+CD25CD107a+ T-Cells in Patients with Autoimmune Diseases Affecting the Central Nervous System. PLoS ONE. 2009; 4(8):e6534. doi:10.1371/journal. pone. 0006534 .

9. Hengires CM, Rino J, Nibbs RJ, Graham GJ, Barata JT. IL-7 induces rapid clathrin-mediated internalization and JAK3-dependent degradation of IL-7R $\alpha$ in T cells. Blood. 2010; 115(16):3269-3277.

10. Faller EM, Ghazawi FM, Cavar M, MacPherson $P A$. IL-7 induces clathrin mediated endocytosis of CD127 and subsequent degradation by the proteasome in primary human CD8 T cells. Immunol. Cell Biol. 2016; 94:196-207.

11. Kang J, Coles M. IL-7: the global builder of the innate lymphoid network and beyond, one niche at a time. Semin Immunol. 2012; 24(3):190-197.

12. Van de Loosdrecht AA, Beelen RH, Ossenkoppele GJ, Broekhoven $M G$, Langenhuijsen MM. A tetrazolium-based colorimetric MTT assay to quantitate human monocyte mediated cytotoxicity against leukemic cells from cell lines and patients with acute myeloid leukaemia. J Immunol. Methods. 1994; 174 (1-2):311-320.

13. Griffin JF, Bulmer R, Wilson EW. Cord blood lymphocyte subpopulations and mitogenic activity in whole blood microculture. J Reprod Immunol. 1979; 1(4):219-27.

14. Burska A, Boissinot M, Ponchel F. Cytokines as Biomarkers in Rheumatoid Arthritis. Mediators of Inflammation. 2014; Article ID 545493, 24 pages http://dx.doi.org/10.1155/2014/545493.

15. Sathaliyawala T, Kubota M, Yudanin N, Turner D, Camp P, Thome JC, Bickham KL, Lerner H, Goldstein M, Sykes M, Kato T, Farber DL. Distribution and compartmentalization of human circulating and tissue-resident memory $\mathrm{T}$ cell subsets. Immunity. 2013; 38(1):187-197.

16. Hassan J, Reen DJ. Human Recent Thymic Emigrants-Identification, Expansion, And Survival Characteristics. Journal Immunol. 2001; 167(4): 1970-1976.

17. Cote S, Matte J, Sad S, Angel JB, Crawley AM. Complexed soluble IL-7 receptor $\alpha$ and IL-7 increase IL-7-mediated proliferation and viability of $\mathrm{CD}^{+}$T-cells in vitro. Cell Immunol. 2015; 293(2):122-125.

18. Akbar AN, Salmon M. Cellular environments and apoptosis: tissue microenvironments control activated T-cell death. Immunol. Today. 1997; 18:72.

19. Bortwick NJ, Lowdell M, Salmon M, Akbar AN. Loss of $\mathrm{CD} 28$ expression on $\mathrm{CD}^{+} \mathrm{T}$ cells is induced by IL-2 receptor $\gamma$ chain signalling cytokines and type I IFN, and increases susceptibility to activation-induced apoptosis. Int Immunol. 2000; 12 (7):10051013.

20. Brodin P, Davis MM. Human immune system variation. Nat Rev Immunol. 2017 Jan;17(1):21-29.

21. Najib Aziz, Roger Detels, Joshua J. Quint, David Gjertson, Timothy Ryner, Anthony W. Butch. Biological variation of immunological blood biomarkers in healthy individuals and quality goals for biomarker tests. BMC Immunology. 2019; 20:33 doi.org/10.1186/s12865-019-0313-0.

\section{Персоналізована відповідь мононуклеарних клітин периферичної крові людини (МНПК) на дію IL-7}

М. В. Ковальчук, Т. П. Рубан, М. О. Усенко, В. А. Кордюм

Інтерлейкін-7 (ІЛ-7) є важливим елементом функціонування імунної системи. Тому було б доцільно оцінити індивідуальні реакції імунних клітин на ІЛ-7. Мета. Проаналізувати ex vivo реакції Т-клітин МНПК здорових дорослих індивідів до зростання концентрації rhIL-7. Методи. Виділення та культивування МНПК та аналіз біологічної активності цитокінів in vitro. Кількісне визначення життєздатності клітин проводили за допомогою МТТ-тесту у живих клітинах. EC $_{50}$ розраховували використовуючи програмне забезпечен- 
ня OriginPro7,5. Результати. Було кількісно оцінено вплив різних концентрацій rhIL-7 на Т-клітини МНПК in vitro у різних індивідів. Аналіз біологічної активності IL-7 виявив, що індивідуальні значення $\mathrm{EC}_{50}$ знаходилися в межах 0,41-1,5 нг/мл. Міжіндивідуальна мінливість була високою для значень $\mathrm{EC}_{50}$ ІЛ-7 $\left(\mathrm{CV}_{\mathrm{G}}=38 \%\right)$. Максимальний відсоток підвищення життєздатності клітин серед суб'єктів демонстрував помірну мінливість $\left(\mathrm{CV}_{\mathrm{G}}=15 \%\right)$. Висновки. Дослідження показало, що існує різниця у відповіді МНПК, отриманих від різних індивідів, до дії ІЛ-7. Наші дослідження припускають, що персоналізована відповідь МНПК людини до ІЛ-7 може вважатися корисною прогностичною інформацією про стан імунної системи та реакцію Т-клітин на лікування на основі препаратів ІЛ-7. Показано перевагу оптимізованого методу за чутливістю детектування індивідуальної відповіді МНПК до ІЛ-7.

К л ю ч о в і с л о в а: ІЛ-7, МНПК, міжіндивідуальна мінливість.

\section{Персонализированный ответ мононуклеарных клеток периферической крови человека (МНПК) на действие ИЛ-7}

\author{
М. В. Ковальчук, Т. А. Рубан, М. А. Усенко, \\ В. А. Кордюм
}

Интерлейкин-7 (ИЛ-7) является важным элементом функционирования иммунной системы. Поэтому было бы целесообразно оценить индивидуальные реакции иммунных клеток на ИЛ-7. Цель. Проанализировать ex vivo реакции Т-клеток МНПК здоровых взрослых индивидов к возрастанию концентрации rhIL-7. Методы. Выделение и культивирование МНПК и анализ биологической активности цитокинов in vitro. Количественное определение жизнеспособности клеток проводили с помощью МТТ-теста в живых клетках. $\mathrm{EC}_{50}$ рассчитывали используя программное обеспечение OriginPro7,5. Результаты. Было количественно оценено влияние различных концентраций rhIL-7 на Т-клетки МНПК in vitro у разных индивидов. Анализ биологической активности ИЛ-7 обнаружил, что индивидуальные значения $\mathrm{EC}_{50}$ находились в пределах 0,41-1,5 нг/мл. Межиндивидуальная изменчивость была высокой для значений $\mathrm{EC}_{50}$ ИЛ-7 $\left(\mathrm{CV}_{\mathrm{G}}=38 \%\right)$. Максимальный процент повышения жизнеспособности клеток среди субъектов демонстрировал умеренную изменчивость $\left(\mathrm{CV}_{\mathrm{G}}=15 \%\right)$. Выводы. Исследование показало, что существует разница в ответе МНПК, полученных от разных индивидов, к действию ИЛ-7. Наши исследования предполагают, что персонализированный ответ МНПК человека к действию ИЛ-7 может считаться полезной прогностической информацией о состоянии иммунной системы и реакции Т-клеток на лечение, основанное на препаратах ИЛ-7. Показано преимущество оптимизированного метода по чувствительности детектирования индивидуального ответа МНПК к ИЛ-7.

К л юч е в ы е с л о в а: ИЛ-7, МНПК, межиндивидуальная изменчивость.

Received 28.04.2020 